NEWS

\title{
French agency head resigns in cancer row
}

The resignation on 8 October of Christian Bréchot, director-general of the French medical research agency, INSERM, is the latest and highest-profile fallout of a bitter conflict about new technologies for screening cancer cells. The dispute pits Bréchot's wife, Patrizia Paterlini-Bréchot, an INSERM oncologist, against the current management of Metagenex, a company the couple founded in 2001. The clash has triggered lawsuits and investigations by France's top ethical and health authorities.

The pair created the firm to commercialize a filtration technique they developed called ISET (isolation by size of epithelial tumour cells). ISET can detect circulating tumour cells (CTCs) in the blood, picking out individual tumour cells from billions of blood cells (G. Vona et al. Am. J. Pathol. 156, 57-63; 2000). Detection of CTCs is a hot area of cancer research. Combined with research on genetic markers, it promises insight into disease progression and metastasis; it could lead to better tailored treatments or, more speculatively, earlier diagnosis.

\section{Promising technique}

Klaus Pantel, chairman of the Institute of Tumor Biology at the University of Hamburg in Germany and an expert in CTCs, says he is a "very strong protagonist" of CTC technology: "I want it to go into the clinic." But he warns against excessive hype for any one system, saying, "it's a complex field". All of the existing systems for analysing CTCs, including contenders from Immunicon of Huntingdon Valley, Pennsylvania, and Veridex, a

"This whole story is bizarre." - Claude Kordon subsidiary of Johnson \& Johnson based in New Jersey, as well as ISET, have their "pros and cons", he adds. "We mustn't push too early, and create too high expectations."

Whether high or not, Metagenex says that its legitimate expectations have been thwarted by the company's founders. On 13 July it filed a lawsuit claiming $€ 43.2$ million (US\$61.3 million) in damages against Bréchot, PaterliniBréchot and INSERM's technology transfer arm, INSERM Transfer. The suit claims that Bréchot and Paterlini-Bréchot "voluntarily paralysed" the company by blocking its access to exclusive licences held by INSERM, the Assistance Publique-Hôpitaux de Paris, and the University of Paris V, promised under a rider to an agreement between the parties.

David Znaty, the company's director-general, claims that this was part of a wider campaign by Paterlini-Bréchot, in particular, to damage the company and eventually force him out. The terms of his contract require him to sell his shares to her in such circumstances. The suit claims Paterlini-Bréchot's motivation was to regain control of the company, a result that the sale of Znaty's shares would provide. On 28 September, Paterlini-Bréchot filed a countersuit against Znaty for the same sum.

Bréchot, who like his wife denies any wrong doing, says that his resignation was in part so that he can have his hands free to fight the case; he also talks of pursuing new career challenges. He vehemently denies the company's accusation that, as the chief official at INSERM, he faced a conflict of interest in decisions about licensing after disagreements arose between his wife and Metagenex's management. He is not a shareholder himself, having divested his shares when he took up his INSERM position. The shares are now held by the couple's children.

The conflict between the company's founders and managers began shortly after Znaty, an engineer and entrepreneur trained at the Massachusetts Institute of Technology, was invited by Paterlini-Bréchot to join the company in April 2006 when it was at risk of bankruptcy. But it got worse after $\mathrm{a} € 2$.5-million investment by AXA, a financial services company, and Banexi, a venture-capital firm, three months later. This reduced the Bréchot family's shareholding from $83 \%$ to $44 \%$.

Paterlini-Bréchot alleges that Metagenex went on to commercialize the ISET technology without fully disclosing its experimental nature, that it broke an agreement to pursue multicentre trials to clinically validate applications for the follow-up of cancer patients, and that it illegally used the test for the commercial diagnosis of cancer. Znaty flatly rejects the allegations as a "smokescreen". His suit in turn

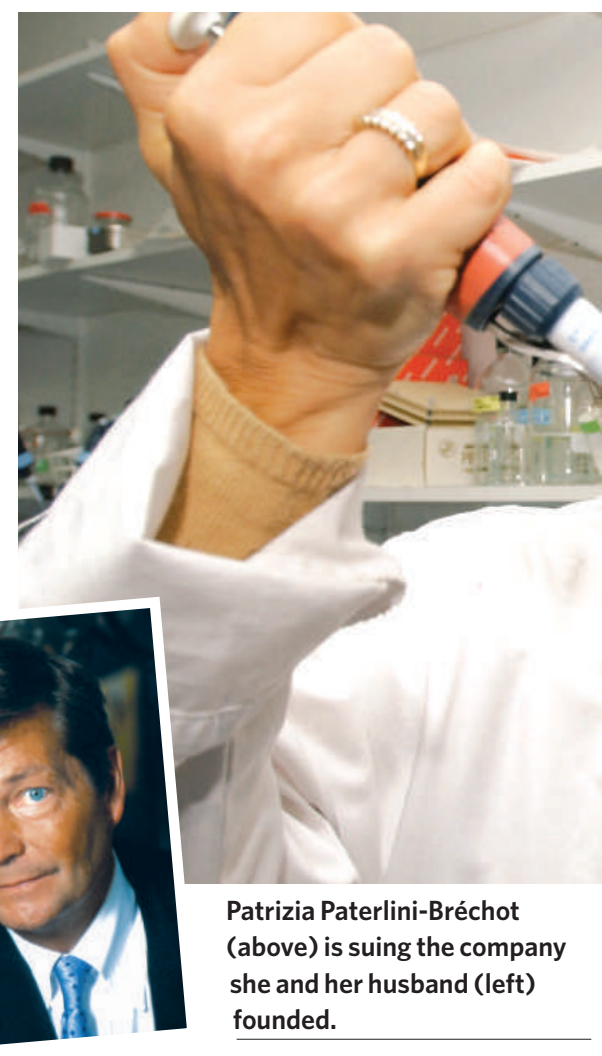

accuses Paterlini-Bréchot of various breaches.

The legal battle is only one side of the dispute, which is also being fought in the arena of medical ethics and public opinion. PaterliniBréchot has personally solicited investigations into the Metagenex affair by the National Consultative Ethics Committee for Health and Life Sciences (CCNE) and INSERM's own ethical committee, billing the Metagenex case as being central to the ethics of developing diagnostics for severe diseases, such as cancer. Reports from both bodies backed the principle that such tests need rigorous multicentre trials to validate their sensitivity and specificity, and to assess any correlation with disease progression. As a result, the government has decided to clarify relevant legislation and to close up some loopholes.

\section{An ethical dilemma?}

Bréchot says that the results of these investigations vindicate the July 2006 decision by the patent holders to block Metagenex's licences until it was clear that the test had been validated clinically. Given that the ethical and legislative situation has now been made clearer, he says, there should no longer be any obstacle to Metagenex having access to the patents. That is perhaps putting a brave face on the matter; Bréchot's resignation was prompted by a letter to INSERM from the research and health ministries on 21 September. The letter said that in 
